\title{
PFC Bridge Converter for Voltage-controlled Adjustable-speed PMBLDCM Drive
}

\author{
Sanjeev Singh ${ }^{\dagger}$ and Bhim Singh*
}

\begin{abstract}
In this paper, a buck DC-DC bridge converter is used as a power factor correction (PFC) converter for feeding a voltage source inverter (VSI) based permanent magnet brushless DC motor (PMBLDCM) drive. The front end of the PFC converter is a diode bridge rectifier (DBR) fed from single phase AC mains. The PMBLDCM is used to drive the compressor of an air conditioner through a three-phase voltage source inverter (VSI) fed from a variable voltage DC link. The speed of the air conditioner is controlled to conserve energy using a new concept of voltage control at a DC link proportional to the desired speed of the PMBLDC motor. Therefore, VSI operates only as an electronic commutator of the PMBLDCM. The current of the PMBLDCM is controlled by setting the reference voltage at the DC link as a ramp. The proposed PMBLDCM drive with voltage control-based PFC converter was designed and modeled. The performance is simulated in Matlab-Simulink environment for an air conditioner compressor load driven through a $3.75 \mathrm{~kW}, 1500 \mathrm{rpm}$ PMBLDC motor. To validate the effectiveness of the proposed speed control scheme, the evaluation results demonstrate improved efficiency of the complete drive with the PFC feature in a wide range of speed and input AC voltage.
\end{abstract}

Keywords: PFC, PMBLDCM, Air conditioner, Buck bridge converter, Voltage control, VSI

\section{Introduction}

The air conditioning (air-con) system is prevalent and inevitable in the cities of developed nations because majority of the population live in high-rise buildings. However, in such applications, air conditioners consume a large amount of energy and constitute a significant part of the total electrical power demand in the domestic sector. Therefore, measures to increase energy efficiency and reduce the energy demand are needed.

Usually, the air conditioner has a compressor driven by a single-phase induction motor; the temperature in the airconditioned zone is regulated over a hysteresis band through the 'on/off' control of the compressor motor. Therefore, the motor is operated only at full load (compressor 'on') at nearly constant speed, i.e., rated speed, [1] because these motors achieve maximum efficiency near the rated load only. The 'on/off' control provides inefficient temperature control with increased losses in the motor during frequent 'on/off' operation. Efforts to improve the efficiency of the existing air-con system using new mechanical and electronic system designs have resulted in marginal improvement in system efficiency; however, the variable speed operation of the air conditioner significantly improves system efficiency [2]. Moreover, the compressor

\footnotetext{
$\dagger \quad$ Corresponding Author: Department of Electrical and Instrumentation Engineering, Sant Longowal Institute of Engineering \& Technology, Longowal, Punjab, India.(sschauhan.sdl@gmail.com)

* Electrical Engineering Department, Indian Institute of Technology Delhi, India.(bhimsinghiitd@gmail.com)

Received: August 11, 2009; Accepted: November 20, 2010
}

driven by a motor with speed control delivers the desired cooling capacity and maintains the room temperature effectively and efficiently.

A permanent magnet brushless DC motor (PMBLDCM) has a wide speed range, high efficiency, rugged construction, ease of control, and low maintenance requirements; it is a good option for an air conditioner compressor. PMBLDCM is a three-phase synchronous motor with permanent magnets (PMs) on the rotor and trapezoidal back electromotive-force (EMF) waveform. The commutation is accomplished by electronic switches, which feed current to the motor windings as a function of the rotor position, thereby replacing the mechanical commutator and brush gear [3-7]. PMBLDCM is operated through a three-phase voltage source inverter (VSI), which is fed from singlephase AC supply using a diode bridge rectifier (DBR), followed by a smoothening DC link capacitor (Fig. 1a). PMBLDCM is supplied by three-phase rectangular current blocks of $120^{\circ}$ duration, in phase with the constant part of the back EMF waveform. These motors need rotor-position information only at the commutation points, e.g., every $60^{\circ}$ electrical in the three-phase, requiring a simple controller for commutation [3-7]. Some efforts [1, 8, 9] have been made to use PMBLDCM in air-con applications in vehicles and in the domestic sector.

The PMBLDC motor is operated at a constant torque (i.e., rated torque) with speed control to improve energy efficiency [9]. In fact, the back-EMF of the PMBLDCM is proportional to the motor speed and the developed torque is proportional to its phase current [3-6]; therefore, a constant torque is maintained by a constant current in the stator 


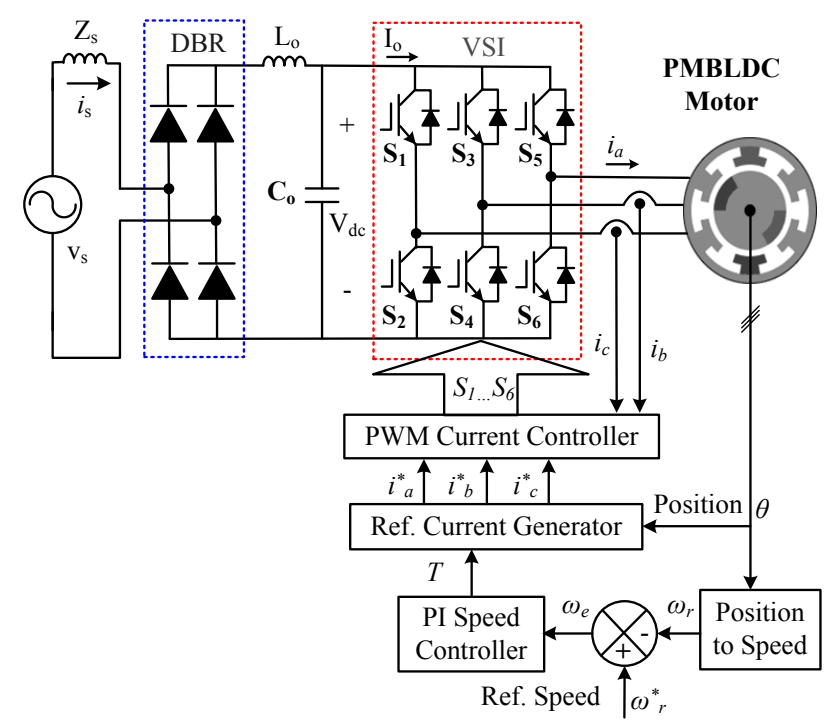

Fig. 1a. Control schematic of conventional PMBLDCM drive.
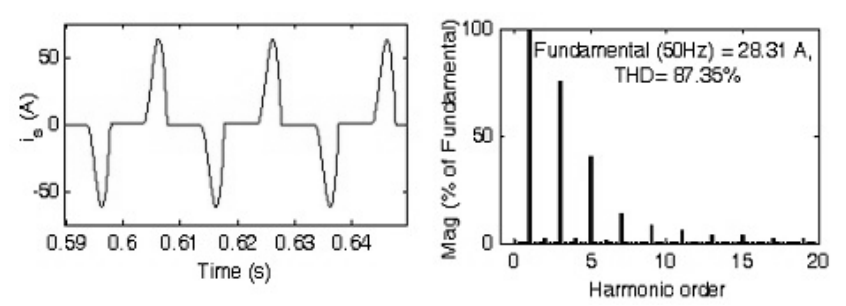

Fig. 1b. Current waveform at input AC mains and the harmonic spectra of the conventional PMBLDCM drive shown in Fig. 1a at a rated torque and 220 VAC input.

winding of the PMBLDCM, whereas the speed can be controlled by varying the terminal voltage of the motor. A new speed control scheme that uses DC link voltage proportional to the desired speed of the PMBLDC motor is used in this work. VSI control is based on the rotor position signals and used only for electronic commutation of the PMBLDC motor.

The PMBLDC motor fed from single-phase AC mains through DBR-VSI, results in power quality (PQ) problems at input $\mathrm{AC}$ mains. These problems include poor power factor, increased total harmonic distortion (THD) in AC mains current, and a high crest factor (CF) as shown in Fig. 1b. These are due to uncontrolled charging of the DC link capacitor, which results in a pulsed current waveform having a peak value higher than the amplitude of the fundamental input current at AC mains. Therefore, suitable measures for mitigation of PQ problems are necessary. Therefore, the use of power factor correction (PFC) topologies [9-19] is recommended for such drives. A standard IEC 61000-3-2 [20] is a power quality standard that outlines allowable limits of different harmonics for the drives in the low power range (current less than $16 \mathrm{~A}$ ).

A DC-DC converter is used as a PFC converter between

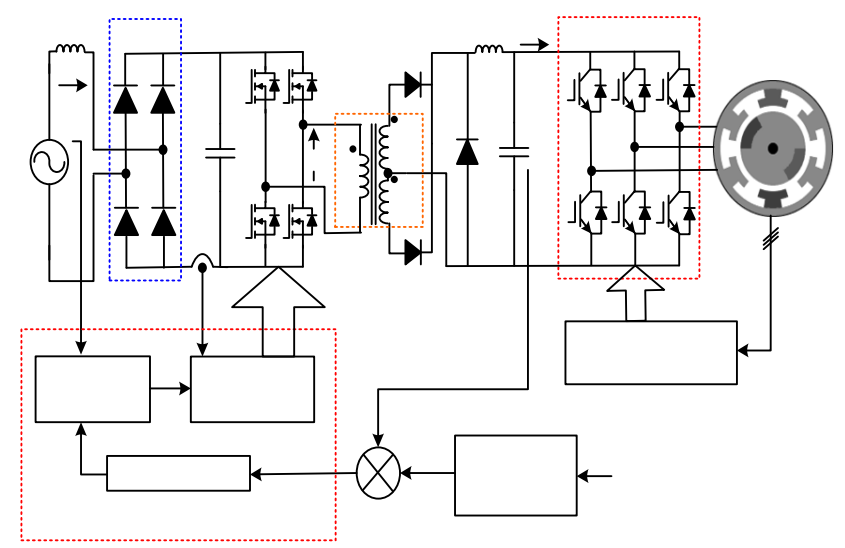

Fig. 1c. Control schematic of the proposed bridge-buck PFC converter fed PMBLDCM drive.

DBR and VSI while feeding the PMBLDCM from the single-phase AC mains [9-11]. The DC-DC converter controls the DC link voltage fed to the VSI from an uncontrolled DC output of DBR, along with power factor (PF) improvement at AC mains through high frequency switching of the converter. A PMBLDCM rated at $3.75 \mathrm{~kW}, 250 \mathrm{~V}$, $1500 \mathrm{rpm}$, and $23.87 \mathrm{Nm}$ torque is used to drive an air conditioner compressor. There are many DC-DC converter topologies available, including buck, boost, and buck-boost with variations of isolated and non-isolated topologies and a number of switches (single, two, or four switches) [1019]. A buck bridge DC-DC converter is used in this work due to the low voltage, isolation, and high power requirements of the load in a wide output voltage range. A detailed modeling, design, and performance evaluation of the proposed speed control scheme with the PFC converter for an air conditioner compressor is presented to demonstrate high efficiency and reduced energy consumption with desired speed control. The features of the speed control using the DC link voltage control, power factor correction at input $\mathrm{AC}$ mains, and reduced THD of AC mains current are added advantages of the buck bridge PFC converter [12-17].

\section{Proposed PMBLDC Motor Speed Control Scheme of Air Conditioners}

The proposed control scheme is shown in Fig. 1c with the commutation control in VSI and speed control (i.e., voltage control) with PFC through a DC-DC converter. It controls the speed by controlling the reference DC link voltage as an equivalent reference speed, thereby replacing the conventional control of the motor speed and a stator current involving various sensors for voltage and current signals. Moreover, the rotor position signals are used to generate the switching sequence for VSI, which acts only as an electronic commutator of the PMBLDC motor. The rotor position of PMBLDCM is sensed using Hall effect position sensors, which are converted to signals for elec- 
Table 1. Back EMF signals based on the Hall effect sensor signals

\begin{tabular}{c|c|c|c|c|c}
\hline $\mathbf{H}_{\mathbf{a}}$ & $\mathbf{H}_{\mathbf{b}}$ & $\mathbf{H}_{\mathbf{c}}$ & $\mathbf{E}_{\mathbf{a}}$ & $\mathbf{E}_{\mathbf{b}}$ & $\mathbf{E}_{\mathbf{c}}$ \\
\hline 0 & 0 & 0 & 0 & 0 & 0 \\
\hline 0 & 0 & 1 & 0 & -1 & +1 \\
\hline 0 & 1 & 0 & -1 & +1 & 0 \\
\hline 0 & 1 & 1 & -1 & 0 & +1 \\
\hline 1 & 0 & 0 & +1 & 0 & -1 \\
\hline 1 & 0 & 1 & +1 & -1 & 0 \\
\hline 1 & 1 & 0 & 0 & +1 & -1 \\
\hline 1 & 1 & 1 & 0 & 0 & 0 \\
\hline
\end{tabular}

Table 2. VSI Switching sequence based on the back EMF signals

\begin{tabular}{c|c|c|c|c|c|c|c|c}
\hline $\mathrm{E}_{\mathrm{a}}$ & $\mathrm{E}_{\mathrm{b}}$ & $\mathrm{E}_{\mathrm{c}}$ & $\mathrm{S}_{1}$ & $\mathrm{~S}_{2}$ & $\mathrm{~S}_{3}$ & $\mathrm{~S}_{4}$ & $\mathrm{~S}_{5}$ & $\mathrm{~S}_{6}$ \\
\hline 0 & 0 & 0 & 0 & 0 & 0 & 0 & 0 & 0 \\
\hline 0 & -1 & +1 & 0 & 0 & 0 & 1 & 1 & 0 \\
\hline-1 & +1 & 0 & 0 & 1 & 1 & 0 & 0 & 0 \\
\hline-1 & 0 & +1 & 0 & 1 & 0 & 0 & 1 & 0 \\
\hline+1 & 0 & -1 & 1 & 0 & 0 & 0 & 0 & 1 \\
\hline+1 & -1 & 0 & 1 & 0 & 0 & 1 & 0 & 0 \\
\hline 0 & +1 & -1 & 0 & 0 & 1 & 0 & 0 & 1 \\
\hline 0 & 0 & 0 & 0 & 0 & 0 & 0 & 0 & 0 \\
\hline
\end{tabular}

tronic commutation as given in Table 1. These signals are used to generate switching sequence for VSI as shown in Table 2 .

The DC link voltage is controlled by a buck bridge DCDC converter based on the duty ratio (D) of the converter. For fast and effective control with reduced size of magnetics and filters, a high switching frequency is used; however, the switching frequency $\left(f_{s}\right)$ is limited by the switching device used, the operating voltage, and the power level, thereby switching losses of the device. Metal oxide field effect transistors (MOSFETs) are used as switching devices for high switching frequency in the proposed PFC buck bridge converter. However, insulated gate bipolar transistors (IGBTs) are used in the VSI bridge, which feeds PMBLDCM to reduce switching stress and EMI filtering issues because it operates at a lower frequency compared with PFC switches.

The PFC control scheme uses a speed (equivalent voltage) control loop inside the current control loop with current multiplier approach. The PFC converter is designed to operate in the continuous conduction mode (CCM) with average current control scheme. The control action begins with the comparison of sensed DC link voltage with a voltage equivalent to the reference speed. The resultant voltage error is passed through a voltage controller to give the modulating current signal. This signal is multiplied with a unit template of input $\mathrm{AC}$ voltage and compared with $\mathrm{DC}$ current sensed after the DBR. The resultant current error is amplified and compared with the saw tooth carrier wave of fixed frequency $\left(\mathrm{f}_{\mathrm{s}}\right)$ to generate PWM pulses for the DCDC converter [18]. The complete control scheme includes sensor selection, control algorithm design, and PWM control of the PFC switch.

\section{Design of the PFC Buck Bridge Converter- based PMBLDCM Drive}

The PFC buck bridge converter is designed for a PMBLDCM drive with a DBR at the front. The parameters of this PFC converter are selected on the basis of PQ constraints at $\mathrm{AC}$ mains and allowable ripple in DC link voltage. The DC link voltage of the PFC converter is given as,

$$
\mathrm{V}_{\mathrm{dc}}=2\left(\mathrm{~N}_{21} / \mathrm{N}_{1}\right) \mathrm{V}_{\text {in }} \mathrm{D} \text { and } \mathrm{N}_{21}=\mathrm{N}_{22}
$$

where $\mathrm{N}_{1}, \mathrm{~N}_{21}$, and $\mathrm{N}_{22}$ are the number of turns in primary, secondary-upper, and lower windings of the high frequency (HF) isolation transformer, respectively.

$\mathrm{V}_{\text {in }}$ is the average output of the DBR for a given AC input voltage $\left(\mathrm{V}_{\mathrm{s}}\right)$ related as

$$
\mathrm{V}_{\text {in }}=2 \sqrt{ } 2 \mathrm{~V}_{\mathrm{s}} / \pi
$$

To reduce the ripples introduced due to high switching frequency, a suitable ripple filter is designed for constant output voltage of the buck bridge converter. The inductance $\left(\mathrm{L}_{\mathrm{o}}\right)$ of an output ripple filter restricts the inductor peak to peak ripple current $\left(\Delta \mathrm{I}_{\mathrm{Lo}}\right)$ within a specified range for the given switching frequency $\left(f_{s}\right)$, whereas the capacitance $\left(\mathrm{C}_{\mathrm{o}}\right)$ is calculated for a specified ripple in the output voltage $\left(\Delta \mathrm{V}_{\mathrm{Co}}\right)$ [18-19]. The output filter inductor and capacitor are given as,

$$
\begin{gathered}
\mathrm{L}_{\mathrm{o}}=(0.5-\mathrm{D}) \mathrm{V}_{\mathrm{dc}} /\left\{\mathrm{f}_{\mathrm{s}}\left(\Delta \mathrm{I}_{\mathrm{Lo}}\right)\right\} \\
\mathrm{C}_{\mathrm{o}}=\mathrm{I}_{\mathrm{o}} /\left(2 \omega \Delta \mathrm{V}_{\mathrm{Co}}\right)
\end{gathered}
$$

The PMBLDCM considered in this work is rated at 3.75 $\mathrm{kW}, 1500 \mathrm{rpm}$. Therefore, the PFC converter is designed at a base DC link voltage of $\mathrm{V}_{\mathrm{dc}}=200 \mathrm{~V}$ at $\mathrm{V}_{\text {in }}=198 \mathrm{~V}$ for $\mathrm{V}_{\mathrm{s}}$ $=220$ Vrms. Other design data include: $\mathrm{f}_{\mathrm{s}}=40 \mathrm{kHz}, \mathrm{I}_{\mathrm{o}}=20$ A, $\Delta \mathrm{V}_{\mathrm{Co}}=6 \mathrm{~V}\left(3 \%\right.$ of $\left.\mathrm{V}_{\mathrm{dc}}\right), \Delta \mathrm{I}_{\mathrm{Lo}}=2.0$ A $\left(10 \%\right.$ of $\left.\mathrm{I}_{\mathrm{o}}\right)$. The design parameters are calculated as $\mathrm{L}_{0}=0.6 \mathrm{mH}$, $\mathrm{C}_{\mathrm{o}}=5000 \mu \mathrm{F}$.

The main components of the proposed PMBLDCM drive are the PFC converter and PMBLDCM drive, which are modeled by mathematical equations. The complete PMBLDCM drive is represented as a combination of the individual models of the PFC converter and the VSI-fed PMBLDCM drive. The modeling is discussed in the next section. 


\section{Modeling of the Proposed PFC Converter-based PMBLDCM Drive}

The modeling of the PFC converter consists of the modeling of a speed controller, a reference current generator, and a PWM controller.

\subsection{Speed Controller}

The speed controller, the prime component of this control scheme, is a proportional-integral (PI) controller that closely tracks the reference speed as an equivalent reference voltage. A voltage gradient less than $800 \mathrm{~V} / \mathrm{s}$ is introduced for the change of DC link voltage during step change of the reference voltage due to the change in the reference speed, which ensures the stator current of PMBLDCM within the specified limits (i.e., double the rated current).

At the $\mathrm{k}^{\text {th }}$ instance of time, $\mathrm{V}^{*}{ }_{\mathrm{dc}}(\mathrm{k})$ is the reference DC link voltage, $\mathrm{V}_{\mathrm{dc}}(\mathrm{k})$ is the sensed DC link voltage, and the voltage error $\mathrm{V}_{\mathrm{e}}(\mathrm{k})$ is calculated as,

$$
\mathrm{V}_{\mathrm{e}}(\mathrm{k})=\mathrm{V}^{*}{ }_{\mathrm{dc}}(\mathrm{k})-\mathrm{V}_{\mathrm{dc}}(\mathrm{k})
$$

The PI controller gives desired control signals after processing this voltage error. The output of the controller $\mathrm{I}_{\mathrm{c}}(\mathrm{k})$ at $\mathrm{k}^{\text {th }}$ instant is given as,

$$
\mathrm{I}_{\mathrm{c}}(\mathrm{k})=\mathrm{I}_{\mathrm{c}}(\mathrm{k}-1)+\mathrm{K}_{\mathrm{p}}\left\{\mathrm{V}_{\mathrm{e}}(\mathrm{k})-\mathrm{V}_{\mathrm{e}}(\mathrm{k}-1)\right\}+\mathrm{K}_{\mathrm{i}} \mathrm{V}_{\mathrm{e}}(\mathrm{k})
$$

where $\mathrm{K}_{\mathrm{p}}$ and $\mathrm{K}_{\mathrm{i}}$ are the proportional and integral gains of the PI controller.

\subsection{Reference Current Generator}

The reference input current of the buck bridge converter is denoted by $\mathrm{i}_{\mathrm{dc}} *$ and is given as,

$$
\mathrm{i}_{\mathrm{dc}} *=\mathrm{I}_{\mathrm{c}}(\mathrm{k}) \mathrm{u}_{\mathrm{vs}}
$$

where $u_{v s}$ is the unit template of the voltage at input AC mains calculated as,

$$
\mathrm{u}_{\mathrm{vs}}=\mathrm{v}_{\mathrm{d}} / \mathrm{V}_{\mathrm{sm}} ; \mathrm{v}_{\mathrm{d}}=\left|\mathrm{v}_{\mathrm{s}}\right| ; \mathrm{v}_{\mathrm{s}}=\mathrm{V}_{\mathrm{sm}} \sin \omega \mathrm{t}
$$

where $\omega$ is the frequency in $\mathrm{rad} / \mathrm{sec}$ at input $\mathrm{AC}$ mains.

\subsection{PWM Controller}

The reference input current of the buck bridge converter $\left(i_{d c}{ }^{*}\right)$ is compared with the sensed current $\left(i_{d c}\right)$ to generate the current error $\Delta \mathrm{i}_{\mathrm{dc}}=\left(\mathrm{i}_{\mathrm{dc}} *-\mathrm{i}_{\mathrm{dc}}\right)$. This current error is amplified by gain $\mathrm{k}_{\mathrm{dc}}$ and compared with fixed frequency $\left(\mathrm{f}_{\mathrm{s}}\right)$ carrier waveforms $m_{d}[18]$ as shown in Fig. 2a to get the switching signals for the MOSFETs of the buck bridge PFC converter. Fig $2 b$ shows simplified carrier waveforms $\mathrm{m}_{\mathrm{d} 1}(\mathrm{t})$ and $\mathrm{m}_{\mathrm{d} 2}(\mathrm{t})$ that are compared with the amplified error

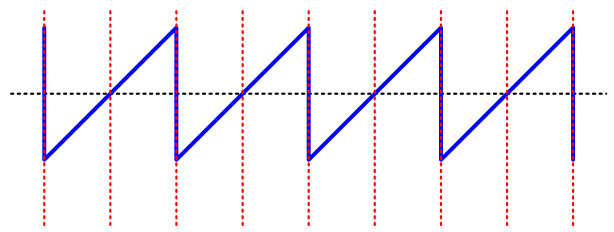

Fig. 2a. PWM Control Scheme of the Proposed Bridgebuck PFC converter.

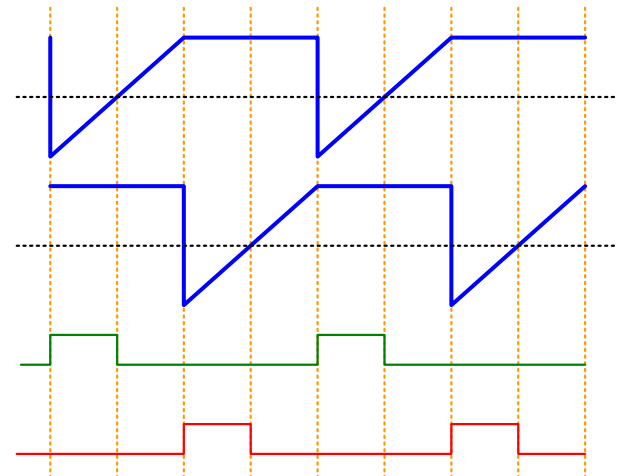

Fig. 2b. PWM Control Scheme of the Proposed Bridgebuck PFC converter.

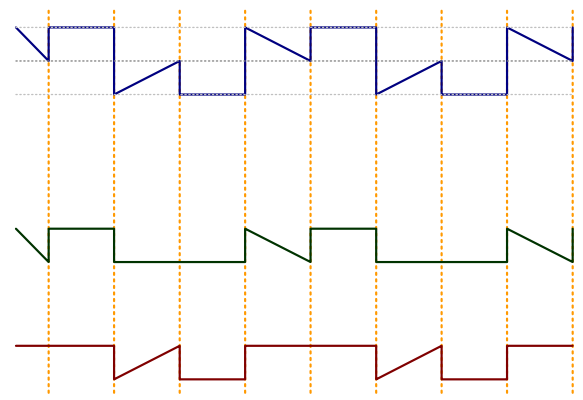

Fig. 2c. Ideal Voltage and Current waveforms of the Bridge-buck PFC converter.

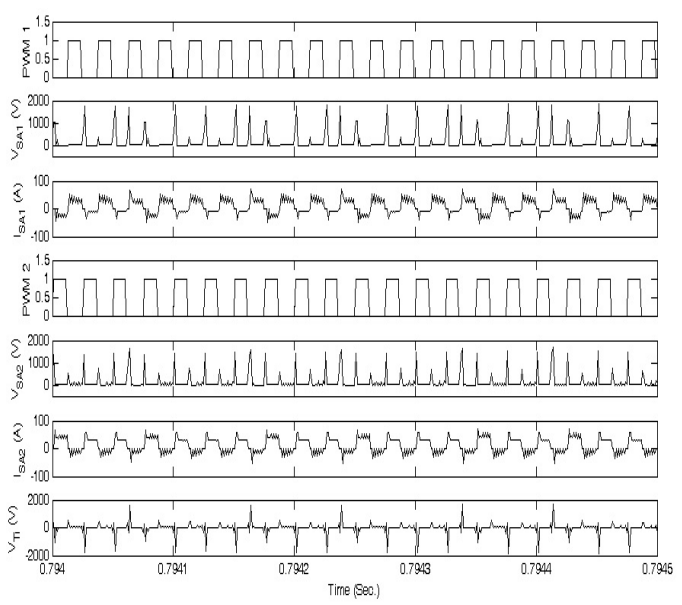

Fig. 2d. Simulated Voltage and Current waveforms of the Proposed Bridge-buck PFC converter during operation of PMBLDCM under steady state condition at Rated torque $(23.87 \mathrm{Nm})$ and $1500 \mathrm{rpm}$ speed. 
$\left(\mathrm{k}_{\mathrm{dc}} \Delta \mathrm{i}_{\mathrm{dc}}\right)$ to get two sets of PWM signals for two pairs of MOSFETs i.e., $\mathrm{S}_{\mathrm{A} 1}, \mathrm{~S}_{\mathrm{B} 2}$ and $\mathrm{S}_{\mathrm{B} 1}, \mathrm{~S}_{\mathrm{A} 2}$ as,

$$
\begin{aligned}
& \text { If } \mathrm{k}_{\mathrm{dc}} \Delta \mathrm{i}_{\mathrm{dc}}>\mathrm{m}_{\mathrm{d} 1}(\mathrm{t}) \text { then } \mathrm{S}_{\mathrm{A} 1}=\mathrm{S}_{\mathrm{B} 2}=1 \text { else } 0 \\
& \text { If } \mathrm{k}_{\mathrm{dc}} \Delta \mathrm{i}_{\mathrm{dc}}>\mathrm{m}_{\mathrm{d} 2}(\mathrm{t}) \text { then } \mathrm{S}_{\mathrm{A} 2}=\mathrm{S}_{\mathrm{B} 1}=1 \text { else } 0
\end{aligned}
$$

where $\mathrm{S}_{\mathrm{A} 1}, \mathrm{~S}_{\mathrm{A} 2}$ and $\mathrm{S}_{\mathrm{B} 1}, \mathrm{~S}_{\mathrm{B} 2}$ are upper and lower switches of different legs of the buck bridge converter (Fig. 1). The values ' 1 ' and ' 0 ' represent the 'on' and 'off' positions of the respective MOSFET of the PFC converter. When none of the MOSFETs are 'ON', the current tends to become zero through feedback diodes $\mathrm{D}_{\mathrm{A} 1}, \mathrm{D}_{\mathrm{A} 2}, \mathrm{D}_{\mathrm{B} 1}$, and $\mathrm{D}_{\mathrm{B} 2}$ of the MOSFETs (Fig. 2c) This results in the appearance of voltage $\mathrm{V}_{\mathrm{Ti}}$ across the input terminals of the high frequency (HF) transformer.

The voltage at the input of the high frequency transformer $\left(\mathrm{V}_{\mathrm{Ti}}\right)$ is given as

$$
\mathrm{V}_{\mathrm{Ti}}=\mathrm{V}_{\text {in }}\left(\mathrm{S}_{\mathrm{A} 1}-\mathrm{S}_{\mathrm{B} 1}\right)
$$

The waveforms of voltage at the input of the high frequency transformer $\left(\mathrm{V}_{\mathrm{Ti}}\right)$, switch voltage, and currents are verified by the simulation results shown in Fig. $2 \mathrm{~d}$. The noise in these waveforms is due to high frequency switching and variation of error $\left(\mathrm{k}_{\mathrm{dc}} \Delta \mathrm{i}_{\mathrm{dc}}\right)$ during the simulation. The turns ratio of the high frequency transformer is taken as 1.9:1 (i.e. $\mathrm{N}_{2} / \mathrm{N}_{1}$ where $\mathrm{N}_{2}=\mathrm{N}_{21}=\mathrm{N}_{22}$ ) to maintain the desired DC link Voltage at low input AC voltages typically at $170 \mathrm{~V}$.

\section{Modeling of the PMBLDCM Drive}

The PMBLDCM drive consists of an electronic commutator, a VSI, and a PMBLDC motor. These components are modeled as given below.

\subsection{Electronic Commutator}

The electronic commutator uses signals from the Hall effect position sensor to generate signals (Table 1). The switching sequence for the voltage source inverter is generated based on the logic given in Table 2 .

\subsection{Voltage Source Inverter (VSI)}

Fig. 3 shows an equivalent circuit of a VSI-fed PMBLDCM. The output of VSI to be fed to phase ' $a$ ' of the PMBLDC motor is given as,

$$
\begin{aligned}
& \mathrm{v}_{\mathrm{ao}}=\left(\mathrm{V}_{\mathrm{dc}} / 2\right) \text { for } \mathrm{S}_{1}=1 \text { and } \mathrm{S}_{2}=0 \\
& \mathrm{v}_{\mathrm{ao}}=\left(-\mathrm{V}_{\mathrm{dc}} / 2\right) \text { for } \mathrm{S}_{2}=1 \text { and } \mathrm{S}_{1}=0 \\
& \mathrm{v}_{\mathrm{ao}}=0 \text { for } \mathrm{S}_{1}=0 \text { and } \mathrm{S}_{2}=0 \\
& \mathrm{v}_{\mathrm{an}}=\mathrm{v}_{\mathrm{ao}}-\mathrm{v}_{\mathrm{no}}
\end{aligned}
$$

where 1 and 0 represent the 'on' and 'off' positions of the

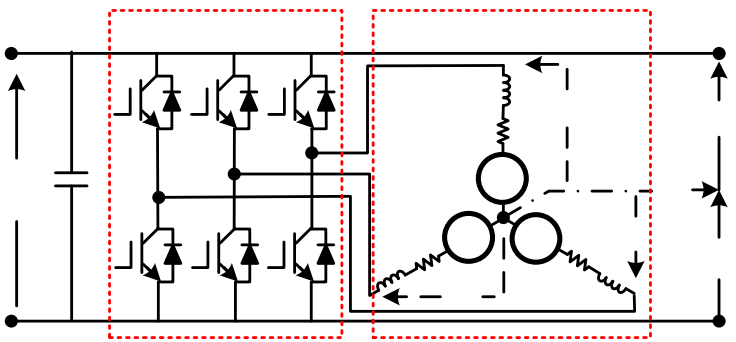

Fig. 3. Equivalent Circuit of a VSI-fed PMBLDCM Drive.

IGBT switch of the VSI, respectively, and are considered in a similar way for other IGBT switches of VSI i.e., $\mathrm{S}_{3}-\mathrm{S}_{6}$.

Using similar logic, $\mathrm{v}_{\mathrm{bo}}, \mathrm{v}_{\mathrm{co}}, \mathrm{v}_{\mathrm{bn}}$, and $\mathrm{v}_{\mathrm{cn}}$ are generated for two other phases of the VSI feeding PMBLDC motor. The voltages $\mathrm{v}_{\mathrm{ao}}, \mathrm{v}_{\mathrm{bo}}, \mathrm{v}_{\mathrm{co}}$, and $\mathrm{v}_{\mathrm{no}}$ are voltages of the threephases and the neutral point (n) with respect to the virtual mid-point of the DC link voltage shown as 'o' in Fig. 3. The voltages $v_{a n}, v_{b n}$, and $v_{c n}$ are voltages of three-phases with respect to the neutral point $(\mathrm{n}) ; \mathrm{V}_{\mathrm{dc}}$ is the DC link voltage.

\subsection{PMBLDC Motor}

The PMBLDCM is modeled in the form of a set of differential equations given as,

$$
\begin{aligned}
& \mathrm{v}_{\mathrm{an}}=\mathrm{Ri}_{\mathrm{a}}+\mathrm{p} \lambda_{\mathrm{a}}+\mathrm{e}_{\mathrm{an}} \\
& \mathrm{v}_{\mathrm{bn}}=\mathrm{Ri}_{\mathrm{b}}+\mathrm{p} \lambda_{\mathrm{b}}+\mathrm{e}_{\mathrm{bn}} \\
& \mathrm{v}_{\mathrm{cn}}=\mathrm{Ri}_{\mathrm{c}}+\mathrm{p} \lambda_{\mathrm{c}}+\mathrm{e}_{\mathrm{cn}}
\end{aligned}
$$

In these equations, $\mathrm{p}$ represents the differential operator $(\mathrm{d} / \mathrm{dt}) ; \mathrm{i}_{\mathrm{a}}, \mathrm{i}_{\mathrm{b}}$, and $\mathrm{i}_{\mathrm{c}}$ are current; $\lambda_{\mathrm{a}}, \lambda_{\mathrm{b}}$, and $\lambda_{\mathrm{c}}$ are flux linkages, and $\mathrm{e}_{\mathrm{an}}, \mathrm{e}_{\mathrm{bn}}$, and $\mathrm{e}_{\mathrm{cn}}$ are the phase to neutral back EMF of PMBLDCM, in respective phases; $\mathrm{R}$ is the resistance of motor windings/phase. Moreover, the flux linkages can be represented as,

$$
\begin{aligned}
& \lambda_{\mathrm{a}}=\mathrm{L}_{\mathrm{s}} \mathrm{i}_{\mathrm{a}}-\mathrm{M}\left(\mathrm{i}_{\mathrm{b}}+\mathrm{i}_{\mathrm{c}}\right) \\
& \lambda_{\mathrm{b}}=\mathrm{L}_{\mathrm{s}} \mathrm{i}_{\mathrm{b}}-\mathrm{M}\left(\mathrm{i}_{\mathrm{a}}+\mathrm{i}_{\mathrm{c}}\right) \\
& \lambda_{\mathrm{c}}=\mathrm{L}_{\mathrm{s}} \mathrm{i}_{\mathrm{c}}-\mathrm{M}\left(\mathrm{i}_{\mathrm{b}}+\mathrm{i}_{\mathrm{a}}\right)
\end{aligned}
$$

where $\mathrm{L}_{\mathrm{s}}$ is the self-inductance/phase, $\mathrm{M}$ is mutual inductance of the motor winding/phase. PMBLDCM has no neutral connection, therefore,

$$
i_{a}+i_{b}+i_{c}=0
$$

From Eqs. (15-22) the voltage $\left(\mathrm{v}_{\mathrm{no}}\right)$ between the neutral point (n) and the mid-point of the DC link (o) is given as,

$$
\mathrm{v}_{\mathrm{no}}=\left\{\mathrm{v}_{\mathrm{ao}}+\mathrm{v}_{\mathrm{bo}}+\mathrm{v}_{\mathrm{co}}-\left(\mathrm{e}_{\mathrm{an}}+\mathrm{e}_{\mathrm{bn}}+\mathrm{e}_{\mathrm{cn}}\right)\right\} / 3
$$

From Eqs. (19-22), the flux linkages are given as,

$$
\lambda_{\mathrm{a}}=\left(\mathrm{L}_{\mathrm{s}}+\mathrm{M}\right) \mathrm{i}_{\mathrm{a}}, \quad \lambda_{\mathrm{b}}=\left(\mathrm{L}_{\mathrm{s}}+\mathrm{M}\right) \mathrm{i}_{\mathrm{b}}, \quad \lambda_{\mathrm{c}}=\left(\mathrm{L}_{\mathrm{s}}+\mathrm{M}\right) \mathrm{i}_{\mathrm{c}}
$$


From Eqs. (16-18 and 24), the current derivatives in the generalized state space form are given as,

$$
p i_{x}=\left(v_{x n}-i_{x} R-e_{x n}\right) /\left(L_{s}+M\right)
$$

where $\mathrm{x}$ represents phase $\mathrm{a}, \mathrm{b}$, or $\mathrm{c}$.

The developed electromagnetic torque $T_{e}$ in the PMBLDCM is given as,

$$
\mathrm{T}_{\mathrm{e}}=\left(\mathrm{e}_{\mathrm{an}} \mathrm{i}_{\mathrm{a}}+\mathrm{e}_{\mathrm{bn}} \mathrm{i}_{\mathrm{b}}+\mathrm{e}_{\mathrm{cn}} \mathrm{i}_{\mathrm{c}}\right) / \omega_{\mathrm{r}}
$$

where $\omega_{\mathrm{r}}$ is the motor speed in $\mathrm{rad} / \mathrm{sec}$,

The back EMFs may be expressed as a function of rotor position $(\theta)$ as,

$$
\mathrm{e}_{\mathrm{xn}}=\mathrm{K}_{\mathrm{b}} f_{x}(\theta) \omega_{\mathrm{r}}
$$

where $\mathrm{x}$ can be phase $\mathrm{a}, \mathrm{b}$, or $\mathrm{c}$; accordingly, $f_{x}(\theta)$ represents function of the rotor position with a maximum value \pm 1 identical to the trapezoidal-induced emf given as,

$$
\begin{aligned}
& f_{a}(\theta)=1 \quad \text { for } 0<\theta<2 \pi / 3 \\
& f_{a}(\theta)=\{(6 / \pi)(\pi-\theta)\}-1 \quad \text { for } 2 \pi / 3<\theta<\pi \\
& f_{a}(\theta)=-1 \quad \text { for } \pi<\theta<5 \pi / 3 \\
& f_{a}(\theta)=\{(6 / \pi)(\theta-2 \pi)\}+1 \quad \text { for } 5 \pi / 3<\theta<2 \pi
\end{aligned}
$$

The functions $f_{b}(\theta)$ and $f_{c}(\theta)$ are similar to $f_{a}(\theta)$ with a phase difference of $120^{\circ}$ and $240^{\circ}$, respectively. Therefore, the electromagnetic torque is expressed as,

$$
\mathrm{T}_{\mathrm{e}}=\mathrm{K}_{\mathrm{b}}\left\{f_{\mathrm{a}}(\theta) \mathrm{i}_{\mathrm{a}}+f_{\mathrm{b}}(\theta) \mathrm{i}_{\mathrm{b}}+f_{\mathrm{c}}(\theta) \mathrm{i}_{\mathrm{c}}\right\}
$$

The mechanical equation of motion in the speed derivative form is given as,

$$
\mathrm{p} \omega_{\mathrm{r}}=(\mathrm{P} / 2)\left(\mathrm{T}_{\mathrm{e}}-\mathrm{T}_{\mathrm{l}}-\mathrm{B} \omega_{\mathrm{r}}\right) /(\mathrm{J})
$$

The derivative of rotor position is given as,

$$
\mathrm{p} \theta=\omega_{\mathrm{r}}
$$

where $\mathrm{P}$ is the number of poles, $\mathrm{T}_{1}$ is the load torque in $\mathrm{Nm}$, $\mathrm{J}$ is the moment of inertia in $\mathrm{kg}-\mathrm{m}^{2}$, and $\mathrm{B}$ is the friction coefficient in Nms/Rad. These equations (16-34) represent the dynamic model of the PMBLDC motor.

\section{Performance Evaluation of the Proposed PMBLDCM Drive}

The proposed PMBLDCM drive is modeled in MatlabSimulink environment and evaluated for an air conditioning compressor load. The compressor behaves as a constant torque load equal to the rated torque with speed control to match air conditioning system requirements. The
PMBLDCM rated $3.75 \mathrm{~kW}$ is used to drive the compressor load of an air conditioner. Detailed data of the motor and simulation parameters are given in the Appendix. The speed of the motor is controlled effectively by controlling the DC link voltage. The performance evaluation of the proposed topology is carried out on the basis of various parameters such as total harmonic distortion $\left(\mathrm{THD}_{\mathrm{i}}\right)$. The crest factor $(\mathrm{CF})$ of the current at input $\mathrm{AC}$ mains, displacement power factor (DPF), power factor (PF), and efficiency of the complete drive $\left(\eta_{\text {drive }}\right)$ at different speeds of the motor. Moreover, these parameters are also evaluated for variable input $\mathrm{AC}$ voltage at a constant $\mathrm{DC}$ link voltage of $245 \mathrm{~V}$, which is equivalent to the $1500 \mathrm{rpm}$ reference speed of the PMBLDCM. The results are shown in Figs. 49 and Tables 3-4 to demonstrate the effectiveness of the proposed PMBLDCM drive in a wide range of speed and input $\mathrm{AC}$ voltage. The comparison of results obtained from conventional topology (Figs. 1a and b) and the proposed buck bridge PFC topology (Figs. 7-9) demonstrates improvement of the PQ indices for the same PMBLDCMD under various operating conditions.

\subsection{Performance during Starting}

The performance of the proposed PMBLDCM drive fed from $220 \mathrm{~V} \mathrm{AC}$ mains during starting at a rated torque and $1000 \mathrm{rpm}$ speed is shown in Fig. 4a. A voltage rate limiter of $800 \mathrm{~V} / \mathrm{s}$ is introduced in the reference voltage to limit the starting current of the motor and the charging current of the DC link capacitor. Therefore, the voltage controller closely tracks the reference voltage ramp, and the motor attains reference speed smoothly within $0.8 \mathrm{sec}$ while keeping the stator current within the desired limits, i.e., double the rated value. The current $\left(i_{s}\right)$ waveform at input $A C$ mains is in-phase with the supply voltage $\left(v_{s}\right)$, demonstrating near unity power factor during the starting period.

\subsection{Performance under Speed Control}

Figs. 4-6 show the performance of the proposed PMBLDCM drive under speed control at a constant rated torque $(23.87 \mathrm{Nm})$ and $220 \mathrm{~V} \mathrm{AC}$ mains supply voltage. These results are categorized as performance during transient and steady state conditions.

Transient Condition: Figs. 4b-d show the performance of the drive during speed control of the compressor. The reference speed is changed from $1000 \mathrm{rpm}$ to $1500 \mathrm{rpm}$ for the rated load performance of the compressor; from $1000 \mathrm{rpm}$ to $750 \mathrm{rpm}$ for the compressor at half the rated load; and from $750 \mathrm{rpm}$ to $300 \mathrm{rpm}$ for the compressor at light load. Speed control is fast and smooth in either direction, i.e., acceleration or retardation. Moreover, the stator current of PMBLDCM is within the allowed limit (twice the rated current) due to the introduction of a rate limiter in the reference voltage. Moreover, near unity power factor is maintained by the drive during these transient conditions.

Steady State Condition: The speed control of the 


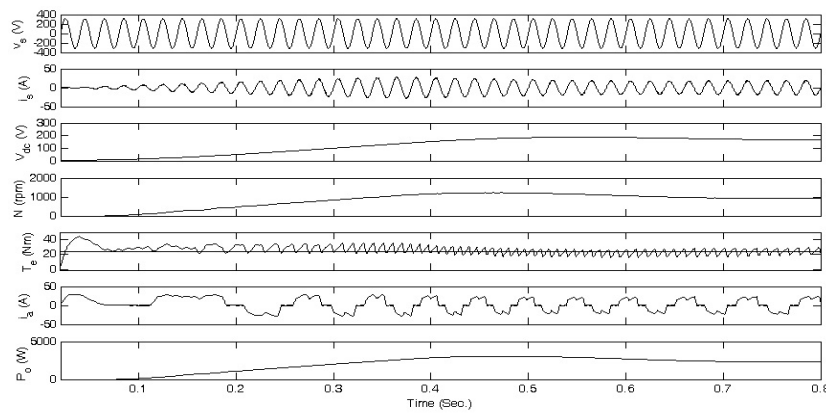

Fig. 4a. Starting performance of the PMBLDCM drive at $1000 \mathrm{rpm}$

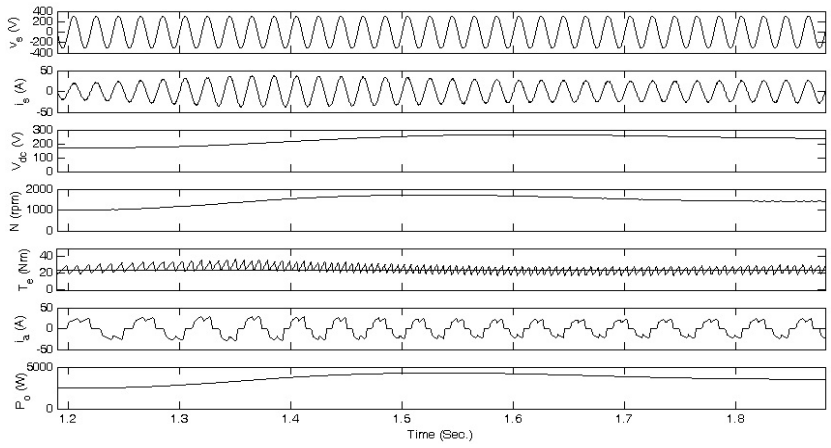

Fig. 4b. Performance of the PMBLDCM drive under speed variation from $1000 \mathrm{rpm}$ to $1500 \mathrm{rpm}$

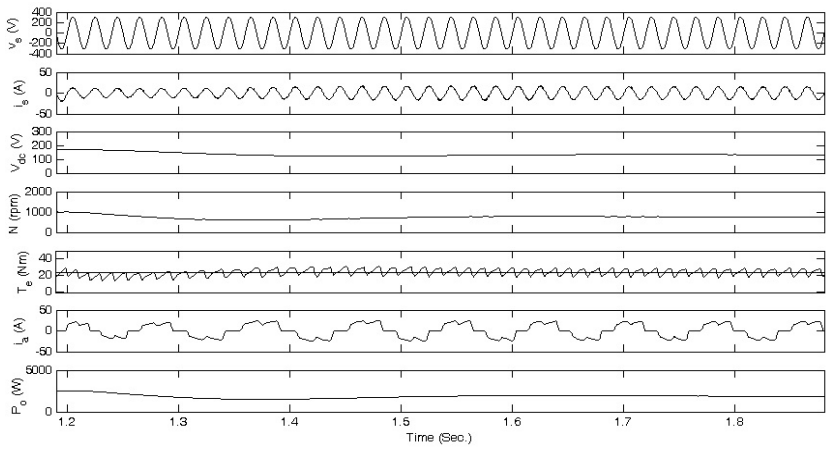

Fig. 4c. Performance of the PMBLDCM drive under speed variation from $1500 \mathrm{rpm}$ to $750 \mathrm{rpm}$

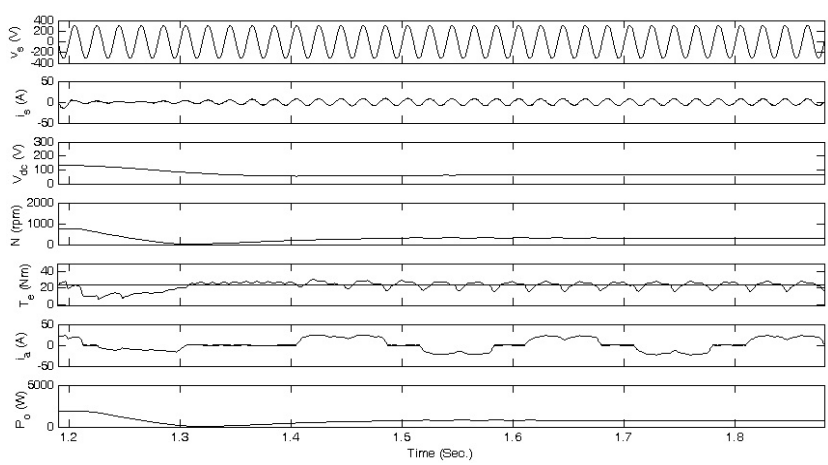

Fig. 4d. Performance of the PMBLDCM drive under speed variation from $750 \mathrm{rpm}$ to $300 \mathrm{rpm}$

Fig. 4. Performance of the PMBLDCM drive under speed variation at $220 \mathrm{VAC}$ input

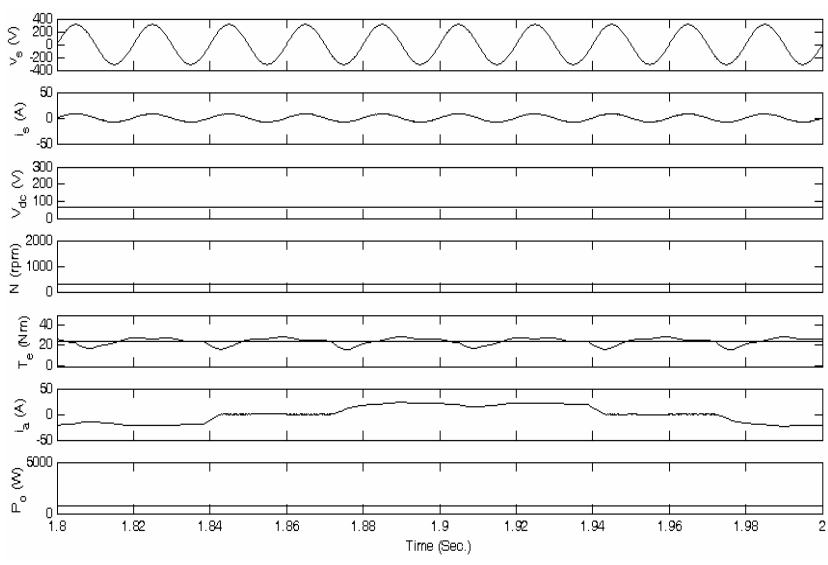

Fig. 5a. Performance of the PMBLDCM drive at $300 \mathrm{rpm}$.

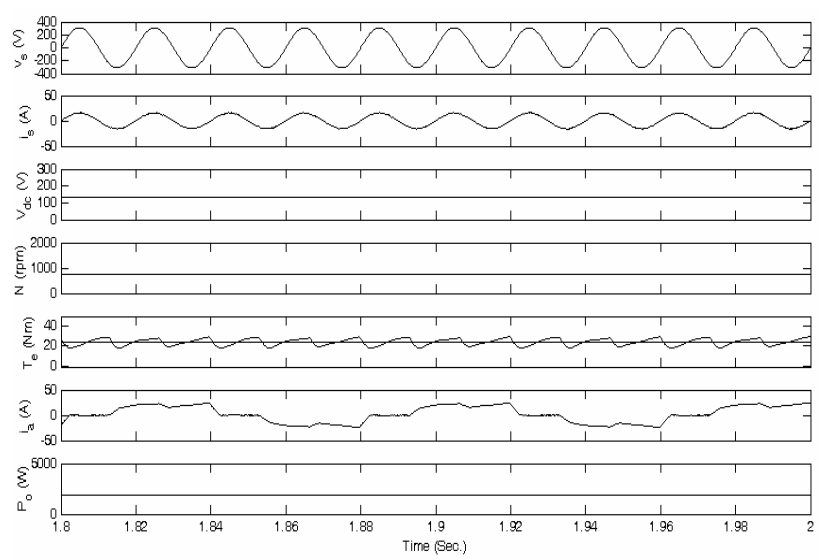

Fig. 5b. Performance of the PMBLDCM drive at $750 \mathrm{rpm}$.

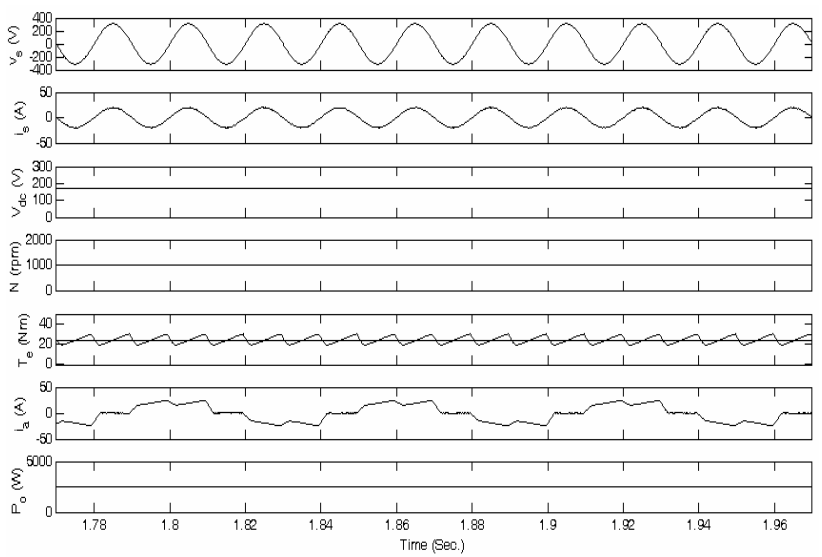

Fig. 5c. Performance of the PMBLDCM drive at $1000 \mathrm{rpm}$.

PMBLDCM-driven compressor under the steady state condition is carried out for different speeds; the results are shown in Figs. 5-6 and Table 1-3 to demonstrate the effectiveness of the proposed drive in a wide speed range. Figs. 5(a-d) show voltage $\left(v_{s}\right)$ and current $\left(i_{s}\right)$ waveforms at AC mains, DC link voltage $\left(\mathrm{V}_{\mathrm{dc}}\right)$, motor speed $(\mathrm{N})$, developed electromagnetic torque of the motor $\left(\mathrm{T}_{\mathrm{e}}\right)$, the stator current 


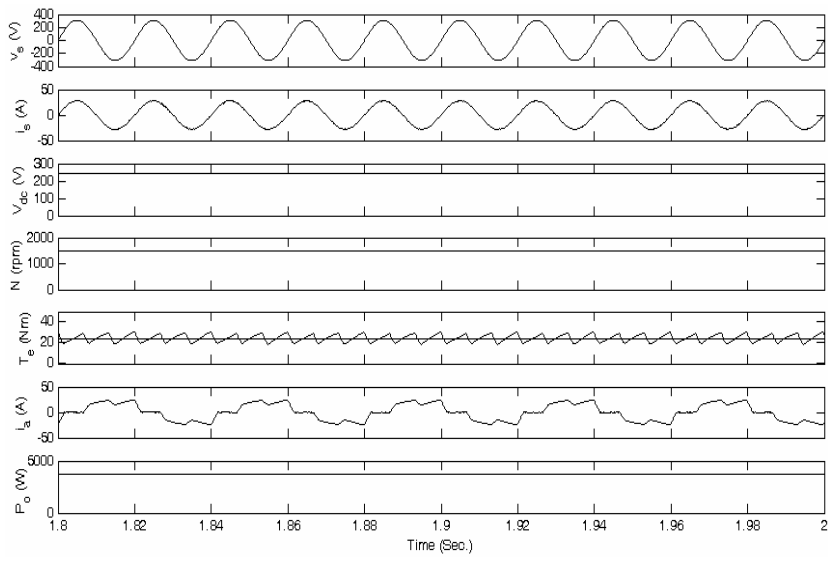

Fig. 5d. Performance of the PMBLDCM drive at $1500 \mathrm{rpm}$.

Fig. 5. Performance of the PMBLDCMD under the steady state condition at $220 \mathrm{VAC}$ input.

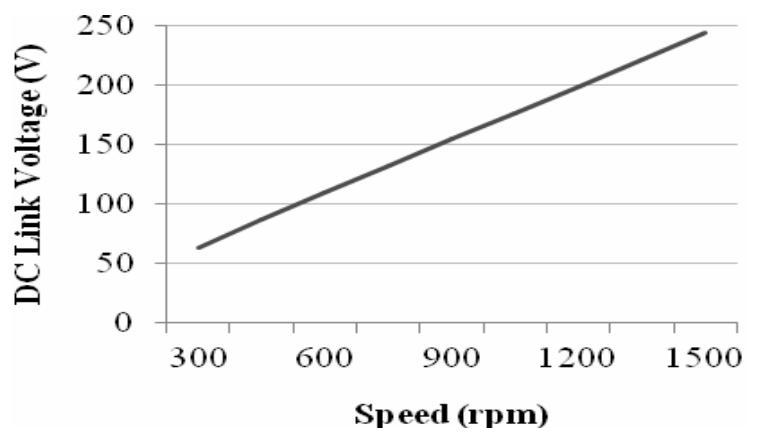

Fig. 6a. Variation of DC link voltage with speed.2

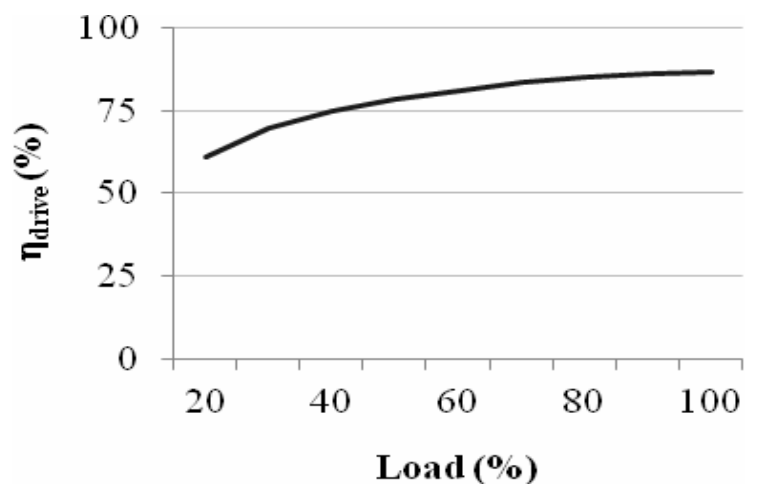

Fig. 6b. Efficiency of complete drive with load.

Fig. 6. Proposed PMBLDCM drive under speed control at a rated torque and $220 \mathrm{~V} \mathrm{AC}$ input.

of the PMBLDC motor for phase ' $a$ ' $\left(\mathrm{I}_{\mathrm{a}}\right)$, and shaft power output $\left(\mathrm{P}_{\mathrm{o}}\right)$ at $300 \mathrm{rpm}, 750 \mathrm{rpm}, 1050 \mathrm{rpm}$, and $1500 \mathrm{rpm}$. Fig. 6(a) shows the linear relation between motor speed and DC link voltage. Since the reference speed is decided by the reference voltage at DC link, control of the reference DC link voltage controls the speed of the motor instantaneously. Fig. 6(b) shows the improved efficiency of the complete drive $\left(\eta_{\text {drive }}\right)$ in a wide range of motor speed.

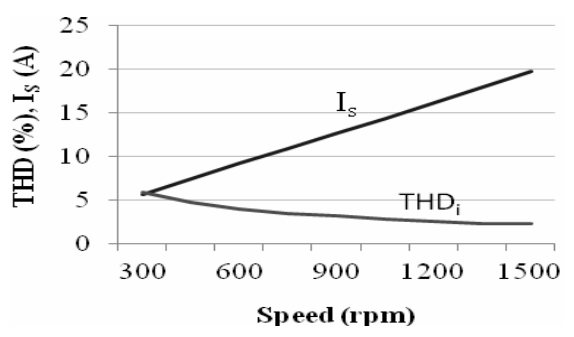

Fig. 7a. Variation of current THD at AC mains.

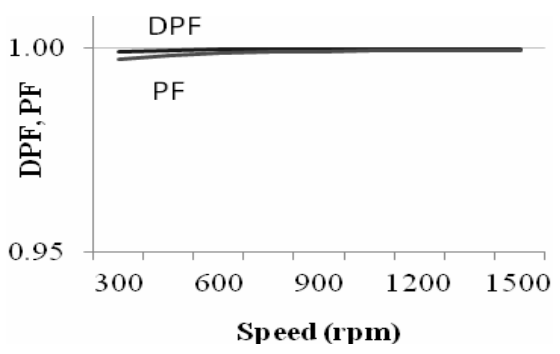

Fig. 7b. Variation of DPF and PF.

Fig. 7. $P Q$ parameters of PMBLDCM drive under speed control at a rated torque and $220 \mathrm{~V}$ AC input.
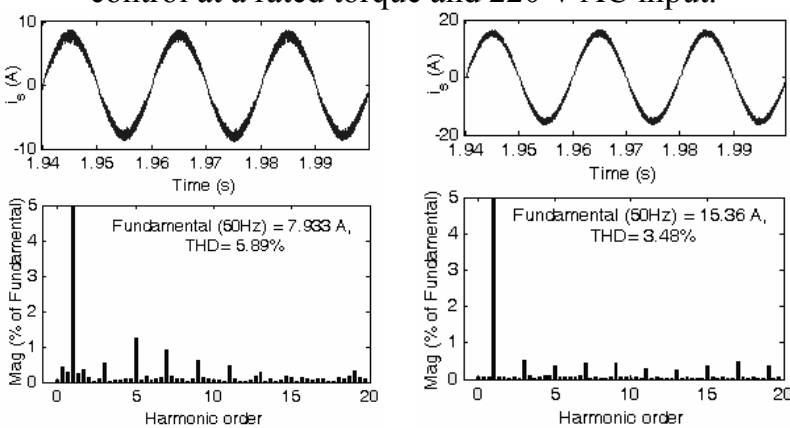

Fig. 8a. THD $_{\mathrm{i}}$ at $300 \mathrm{rpm}$
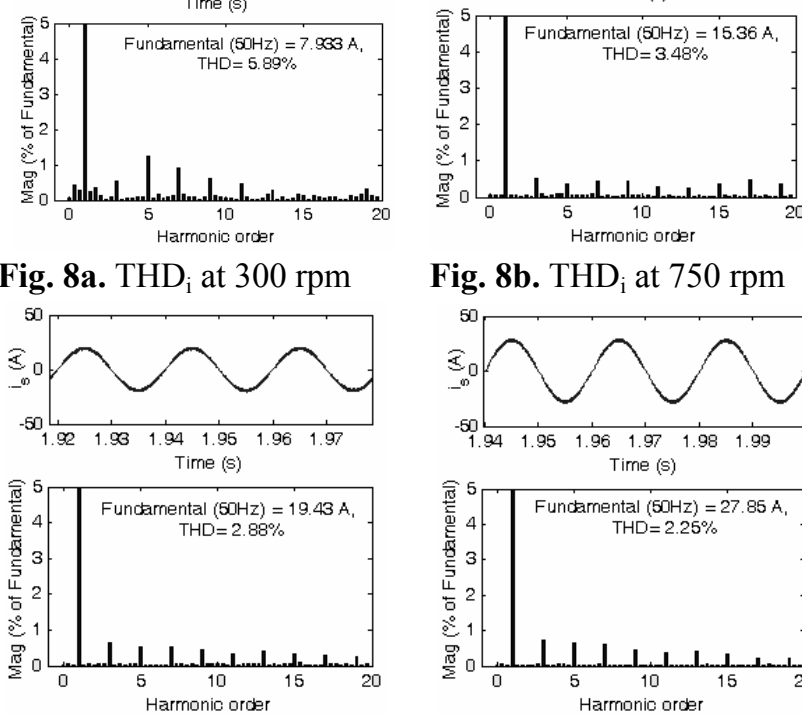

Fig. 8b. $\mathrm{THD}_{\mathrm{i}}$ at $750 \mathrm{rpm}$
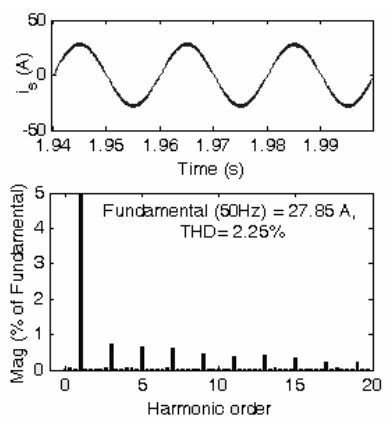

Fig. 8c. THD $_{\mathrm{i}}$ at $1000 \mathrm{rpm}$

Fig. 8d. $\mathrm{THD}_{\mathrm{i}}$ at $1500 \mathrm{rpm}$

Fig. 8. Current waveform at input AC mains and harmonic spectra of the PMBLDCM drive under the steady state condition at a rated torque and $220 \mathrm{VAC}$ input.

\subsection{Power Quality Performance}

The performance of the proposed PMBLDCM drive in terms of various PQ parameters such as $\mathrm{THD}_{\mathrm{i}}, \mathrm{CF}, \mathrm{DPF}$, and PF is summarized in Table 3 and shown in Figs. 7-8. Near unity power factor (PF) and reduced THD of the AC mains current are observed in a wide speed range of the 
Table 3. Performance under speed control at $220 \mathrm{~V}$ input AC voltage $\left(\mathrm{V}_{\mathrm{s}}\right)$

\begin{tabular}{c|c|c|c|c|c|c}
\hline Speed (rpm) & $\mathrm{V}_{\mathrm{DC}}(\mathrm{V})$ & $\eta_{\text {drive }}(\%)$ & Load (\%) & $\begin{array}{c}\mathrm{THD}_{\mathrm{i}} \\
(\%)\end{array}$ & $\mathrm{DPF}$ & $\mathrm{PF}$ \\
\hline 300 & 64 & 60.8 & 20 & 5.89 & 0.9992 & 0.9975 \\
\hline 450 & 87 & 69.6 & 30 & 4.77 & 0.9994 & 0.9983 \\
\hline 600 & 110 & 74.5 & 40 & 3.95 & 0.9998 & 0.9990 \\
\hline 750 & 132 & 78.4 & 50 & 3.48 & 0.9997 & 0.9991 \\
\hline 900 & 155 & 80.9 & 60 & 3.13 & 0.9997 & 0.9992 \\
\hline 1050 & 177 & 83.3 & 70 & 2.77 & 0.9998 & 0.9994 \\
\hline 1200 & 199 & 84.8 & 80 & 2.56 & 0.9998 & 0.9995 \\
\hline 1350 & 222 & 85.9 & 90 & 2.31 & 0.9999 & 0.9996 \\
\hline 1500 & 245 & 86.5 & 100 & 2.25 & 0.9999 & 0.9996 \\
\hline
\end{tabular}

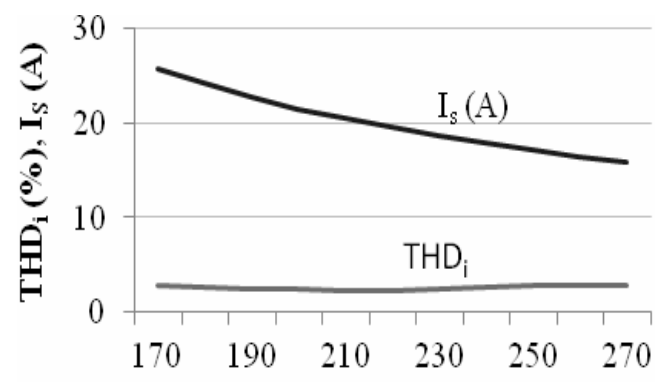

\section{AC Input Voltage (V)}

Fig. 9a. Variation of current at AC mains and the corresponding THD.

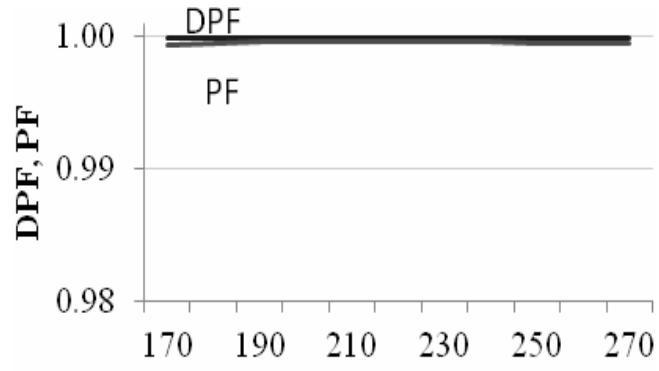

\section{AC Input Voltage (V)}

Fig. 9b. Variation of DPF and PF.

Fig. 9. $P Q$ parameters with input $A C$ voltage at a $D C$ link voltage of $245 \mathrm{~V}$ (equivalent to $1500 \mathrm{rpm}$ ).

PMBLDCM (Figs. 7a-b). THD of AC mains current remains around $5 \%$ along with near unity $\mathrm{PF}$ in a wide range of speed and load (Table 3) (Figs. 8a-d).

\subsection{Performance under Varying Input AC Voltage}

Performance evaluation of the proposed PMBLDCM
Table 4. Variation of PQ parameters with input AC voltage $\left(\mathrm{V}_{\mathrm{s}}\right)$ at $1500 \mathrm{rpm}\left(245 \mathrm{~V}_{\mathrm{dc}}\right)$

\begin{tabular}{c|c|c|c|c|c|c}
\hline $\mathrm{V}_{\mathrm{AC}}(\mathrm{V})$ & $\mathrm{THD}_{\mathrm{i}}(\%)$ & $\mathrm{DPF}$ & $\mathrm{PF}$ & $\mathrm{CF}$ & $\mathrm{I}_{\mathrm{s}}(\mathrm{A})$ & $\eta_{\text {drive }}(\%)$ \\
\hline 170 & 2.92 & 0.9998 & 0.9994 & 1.41 & 25.8 & 85.5 \\
\hline 180 & 2.63 & 0.9998 & 0.9995 & 1.41 & 24.3 & 85.9 \\
\hline 190 & 2.51 & 0.9999 & 0.9996 & 1.41 & 22.9 & 86.2 \\
\hline 200 & 2.42 & 0.9999 & 0.9996 & 1.41 & 21.6 & 86.7 \\
\hline 210 & 2.34 & 0.9999 & 0.9996 & 1.41 & 20.6 & 86.9 \\
\hline 220 & 2.25 & 0.9999 & 0.9996 & 1.41 & 19.7 & 86.5 \\
\hline 230 & 2.51 & 0.9999 & 0.9996 & 1.41 & 18.7 & 87.2 \\
\hline 240 & 2.63 & 0.9999 & 0.9996 & 1.41 & 17.9 & 87.2 \\
\hline 250 & 2.85 & 0.9999 & 0.9995 & 1.41 & 17.2 & 87.2 \\
\hline 260 & 2.89 & 0.9999 & 0.9995 & 1.41 & 16.6 & 87.1 \\
\hline 270 & 2.91 & 0.9999 & 0.9995 & 1.41 & 16.0 & 87.1 \\
\hline
\end{tabular}

drive is carried out under varying input $\mathrm{AC}$ voltages at rated load (i.e., rated torque and rated speed) to demonstrate the operation of the proposed PMBLDCM drive for air conditioning systems in various practical situations as summarized in Table 4.

Figs. 9(a-b) show variation of input current and THD at AC mains, DPF and PF with AC input voltage. THD of the current at $\mathrm{AC}$ mains is within the specified limits of international norms [20] along with near unity power factor in a wide range of $\mathrm{AC}$ input voltage. However, at low $\mathrm{AC}$ input voltage, the performance of the drive deteriorates and the motor takes a comparatively longer time to reach the steady state condition.

\section{Conclusion}

A new speed control strategy for a PMBLDCM drive is validated for a compressor load of an air conditioner, which uses the reference speed as an equivalent reference voltage at DC link. Speed control is directly proportional to voltage control at the DC link. The rate limiter introduced in the reference voltage at the DC link effectively limits the motor current within the desired value during transient conditions (starting and speed control). The additional PFC feature of the proposed drive ensures near unity $\mathrm{PF}$ in a wide range of speed and input $\mathrm{AC}$ voltage. It demonstrates improvements in power quality indices compared with conventional PMBLDCMD topology. Moreover, power quality parameters of the proposed PMBLDCM drive are in conformity to international standard IEC 61000-3-2 [20]. The proposed drive demonstrates good speed control with energy efficient operation of a complete drive system in a wide range of speed and input $\mathrm{AC}$ voltage. The proposed 
buck bridge PFC drive is promising for low-voltage highcurrent PMBLDCM-driven air-con loads within the 3-5 $\mathrm{kW}$ power range.

\section{References}

[1] A.M. Jungreis and A.W. Kelley, "Adjustable speed drive for residential applications," IEEE Trans. Industry Appl., Vol. 31, No. 6, pp. 1315-1322, Nov.Dec. 1995.

[2] T.-W. Chun, J.-R. Ahn, H.-H. Lee, H.-G. Kim and E.-C. Nho, "A Novel Strategy of Efficiency Control for a Linear Compressor System Driven by a PWM Inverter," IEEE Trans. Ind. Electron., Vol. 55, No. 1, pp. 296-301, Jan. 2008.

[3] T. Kenjo and S. Nagamori, Permanent Magnet Brushless DC Motors, Clarendon Press, oxford, 1985.

[4] T. J. Sokira and W. Jaffe, Brushless DC Motors: Electronic Commutation and Control, Tab Books USA, 1989.

[5] J. R. Hendershort Jr and T. J. E. Miller, Design of Brushless Permanent-Magnet Motors, Clarendon Press, Oxford, 1994.

[6] J. F. Gieras and M. Wing, Permanent Magnet Motor Technology - Design and Application, Marcel Dekker

Inc., New York, 2002.

[7] P. Pillay and R. Krishnan, "Modeling, simulation and analysis of a permanent magnet brushless $\mathrm{dc}$ motor drives, part II: the brushless dc motor drive," IEEE Trans. Ind. Appl., Vol. 25, No. 2, pp. 274-279, Mar./Apr. 1989.

[8] M. Naidu, T.W. Nehl, S. Gopalakrishnan and L. Wurth, "Keeping cool while saving space and money: a semi-integrated, sensorless PM brushless drive for a 42-V automotive HVAC compressor," IEEE Ind. Appl. Mag., Vol. 11, No. 4, pp. 20-28, July-Aug. 2005.

[9] Bhim Singh, B.P. Singh and M Kumar, "PFC converter fed PMBLDC motor drive for air conditioning," IE(I) Journal-EL, Vol. 84, pp. 22-27, June 2003.

[10] O. García, J.A. Cobos, R. Prieto, P. Alou and J. Uceda, "Single Phase Power factor correction: A survey," IEEE Trans. Power Electron., Vol. 18, pp. 749-755, May 2003.

[11] A. Barkley, D. Michaud, E. Santi, A. Monti and D. Patterson, "Single stage brushless DC motor drive with high input power factor for single phase applications," in Proc. IEEE PESC, 2006, pp. 1-10.

[12] N. Ismail, P. Jain and H.Soin, "A power factor corrected single stage full bridge $\mathrm{AC} / \mathrm{DC}$ converter topology with zero switching losses," in Proc. IEEE APEC, 1997, Vol.1, pp. 464-470.

[13] C.H. Chan and M.H. Pong, "A fast response full bridge power factor corrector," in Proc. IEEE PESC, 1998, Vol. 2, pp. 1436-1442.

[14] A. Victor, A. Anunciada and R.D. Monteiro, "Single stage full bridge converter with power factor correction," in Proc. IEEE PESC, 2001, Vol. 3, pp. 1566-1570.

[15] C.A. Gallo, J.A.C. Pinto, L.C. de Freitas, V.J. Farias, E.A.A.Coelho and J.B. Vieira, "An unity high power factor power supply rectifier using a PWM AC/DC full bridge soft-switching," in Proc. IEEE APEC, 2002, Vol. 2, pp. 1190-1194.

[16] J.C. Crebier and J.P. Ferrieux, "PFC full bridge rectifiers EMI modeling and analysis-common mode disturbance reduction," IEEE Trans. Power Electron., Vol. 19, No.2, pp. 378-387, March 2004.

[17] T.S. Kim, G.B. Koo, G.W. Moon and M.J. Youn, “A single-stage power factor correction AC/DC converter based on zero voltage switching full bridge topology with two series-connected transformers," IEEE Trans. Power Electron., Vol. 21, No. 1, pp.89-97, Jan. 2006.

[18] N. Mohan, T. Undeland and W. Robbins, Power Electronics: Converters, Applications and Design, Second Edition, New York: John Wiley \& Sons, 1995.

[19] A. I. Pressman, Switching Power Supply Design. Second Edition, New York: McGraw-Hill, 1998.

[20] Limits for Harmonic Current Emissions (Equipment input current $\leq 16$ A per phase), International Standard IEC 61000-3-2, 2000.

\section{Appendix}

Rated Power: $3.75 \mathrm{~kW}$, Rated Speed: $1500 \mathrm{rpm}$, Rated Current: 20.0 A, Rated torque: 23.87 Nm, No of poles: 4, Resistance: $0.54 \mathrm{ohm} / \mathrm{ph}$., Inductance $(\mathrm{L}+\mathrm{M})$ : $0.00891 \mathrm{H} / \mathrm{ph}$., Back EMF constant: $0.615 \mathrm{Vsec} / \mathrm{rad}$, Moment of Inertia $=0.013 \mathrm{Kg}-\mathrm{m}^{2}$. Source impedance $\left(\mathrm{Z}_{\mathrm{s}}\right)$ : $0.03 \mathrm{pu}$, Switching frequency of $\mathrm{PFC}$ switch $\left(\mathrm{f}_{\mathrm{s}}\right)=40 \mathrm{kHz}, \quad \mathrm{L}_{\mathrm{f}}=2.5 \mathrm{mH}, \quad \mathrm{C}_{\mathrm{f}}=0.01 \mu \mathrm{F}, \quad \mathrm{K}_{\mathrm{p}}=0.185$, $\mathrm{K}_{\mathrm{i}}=2.15$. 


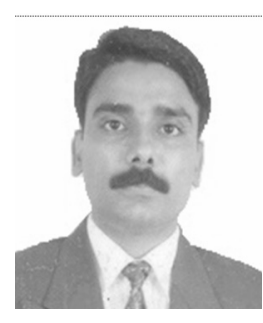

Sanjeev Singh received a B.E (Electrical) degree from the A.P.S. University, Rewa, India, in 1993 and an M.Tech degree from DAVV, Indore, India, in 1997. His expertise includes power electronics, electrical machines and drives, energy efficiency, and power quality.

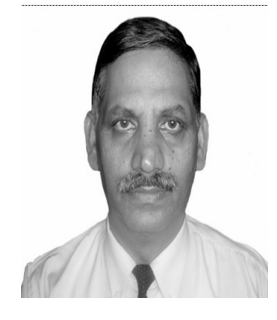

Bhim Singh received a B.E (Electrical) degree from the University of Roorkee, Roorkee, India, in 1977, an M.Tech degree and Ph.D from the Indian Institute of Technology (IIT) Delhi, New Delhi, India, in 1979 and 1983, respectively. His expertise includes power electronics, electrical machines and drives, active filters, FACTS, HVDC, and power quality. 